\title{
Motor learning in children and adolescents institutionalized in shelters
}

\section{Aprendizagem motora em crianças e adolescentes institucionalizados em abrigo}

\section{Caroline Moreira Souza Santos ${ }^{[\mathrm{a}]}$, Marcela Montovanelli Rodrigues ${ }^{[\mathrm{a}]}$, Deborah Cristina Gonçalves Luiz Fernani ${ }^{[a, b]}$, Ana Paula Coelho Figueira Freire ${ }^{[a]}$, Carlos Bandeira de Mello Monteiro ${ }^{[\mathrm{b}, \mathrm{c}]}$, Maria Tereza Artero Prado ${ }^{[\mathrm{a}, \mathrm{b}]^{*}}$}

[a] Universidade do Oeste Paulista (UNOESTE), Presidente Prudente, SP, Brazil

[b] Faculdade de Medicina do ABC (FMABC), Santo André, SP, Brazil

[c] Universidade de São Paulo (USP), São Paulo, SP, Brazil

\begin{abstract}
Introduction: Children and adolescents living in shelters may present with impaired motor development, cognitive function, as well as speech and understanding; psychological alterations; and hyperactivity. All of these factors may be detrimental to motor learning. Objective: To investigate motor learning in children and adolescents living in shelters, and to compare it with that of individuals living in a family context. Methods: We assessed 36 individuals who were divided into groups: an experimental group, composed of institutionalized children and adolescents (EG, $n=18)$, and a control group (CG, $n=18$ ) that was matched by age and sex. Motor learning was assessed using a maze test in three stages: acquisition, retention and transfer. The data were analyzed using the Shapiro Wilk, Wilcoxon, Mann Whitney, Kruskal Wallis tests and Dunn's post-test $(p<5 \%)$. Results: The EG had a longer task performance time than the CG. There was a significant reduction in task performance time between the first (EG = 11.05 [8.50-14.85]s; CG:7.65 [5.95-10.23]s) and the last task performance block (EG:8.02 [6.86-10.23]s; GC: 5.50 [4.50-6.82]s) in both groups. When comparing the
\end{abstract}

* CMSS: BS, e-mail: carolinemoreira93@hotmail.com MMR: BS, e-mail: ma_montovanelli@hotmail.com DCGLF: PhD, e-mail: deborah@unoeste.br APCFF: PhD student, e-mail: anapaulafreire@unoeste.br CBMM: PhD, e-mail: monteiro.carlosbm@gmail.com MTAP: PhD student, e-mail: mariatereza@unoeste.br 
variables of the last acquisition (GE:8.02[6.86-10.23]s; GC: 5.50[4.50-6.82]s), retention (GE:8.20[7.09-9.89] s;GC:5.35[4.50-6.22]s) and transfer blocks (GE:8.30[6.28-11.43]s; GC:5.30[4.90-6.82]s) in each group, we found no changes in task performance time between test batteries. Conclusion: Individuals living in shelters showed a motor learning deficit, as evidenced by longer task performance time when compared to their controls. Nevertheless, both groups performed the task in a similar manner.

Keywords: Maze Learning. Shelter. Institutionalization. Child. Adolescent.

\section{Resumo}

Introdução: Crianças e adolescentes institucionalizados podem apresentar comprometimentos do desenvolvimento motor; das funções cognitiva, da fala, da compreensão; alterações psicológicas e hiperatividade, que podem ser prejudiciais para a aprendizagem motora. Objetivo: Analisar a aprendizagem motora de crianças e adolescentes institucionalizados em abrigo e comparar com indivíduos em contexto familiar. Métodos: Foram avaliados 36 indivíduos divididos em 2 grupos: grupo experimental, composto por crianças e adolescentes institucionalizados (GE, $n=18$ ) e grupo controle (GC, $n=18)$, pareados por sexo e idade. Para avaliação da aprendizagem motora foi utilizada a tarefa de labirinto realizada em três fases: aquisição, retenção e transferência. Para análise dos dados foram utilizados os testes de Shapiro Wilk, Wilcoxon, Mann Whitney, Kruskal Wallis e pós-teste de Dunn ( $p<5 \%)$. Resultados: $O$ GE obteve maior tempo para execução da tarefa comparado com o GC. Houve diminuição significativa do tempo de execução da tarefa, do primeiro bloco (GE $=11,05$ [8,50-14,85]s; GC:7,65 [5,95-10,23]s) para o último bloco da aquisição (GE:8,02 [6,86-10,23]s; GC: 5,50 [4,50-6,82]s) em ambos os grupos. Ao comparar as variáveis entre o último bloco da aquisição (GE:8,02[6,86-10,23]s; GC:5,50[4,50-6,82]s), retenção(GE:8,20[7,09-9,89]s; GC:5,35[4,50-6,22]s) etransferência (GE:8,30[6,28-11,43]s; GC:5,30[4,90-6,82]s) em cada grupo, foi encontrada a manutenção do tempo para execução da tarefa durante as fases. Conclusão: Os indivíduos institucionalizados em abrigo apresentaram um déficit na aprendizagem motora, verificada pelo maior tempo de execução da tarefa comparado aos indivíduos não institucionalizados, porém ambos evoluem de maneira semelhante durante a realização da tarefa.

Palavras-chave: Aprendizagem em Labirinto. Institucionalização. Criança. Adolescente.

\section{Introduction}

Shelters are aimed at providing protection and a home to children and adolescents who are at-risk, as stated in the Child and Adolescent Statute (Articles 90 to 94) (1). Children and adolescents usually live in shelters because they have been abandoned by their families, have become orphans or have been taken away from their from their parents for many different reasons, including: abandonment, maltreatment, neglect, battering, begging or sexual abuse $(2,3)$.

The United Nations Children's Fund (UNICEF) estimates that at least 8 million children live in institutional environments around the world (3). In Brazil, according tothe National Survey of Children and Adolescents in Foster Care, performed by the Ministry of Social Development (4), there were
36,551 children and adolescents institutionalized in 1,991 shelters in 2010.

Children and adolescents living in shelters may present with impaired motor development, cognitive function $(5,6)$, and speech (7), as well as hyperactivity (8) and psychological alterations such as personality disorders $(9,10)$. These impairments may be caused by lack of family affection, rejection from shelter peers and social discrimination (2). All of these factors may be detrimental to motor learning.

Motor learning (ML) is defined as the ability to perform a task with improved performance due to experience and practice $(11,12)$. Thus, three stages are important in the analysis of ML: acquisition, retention and transfer (13). In the acquisition stage, individuals make several attempts to adapt to a new task. They activate the cognitive, emotional 
and attentional process to perform the task (14). In the retention stage, after a period without practice, it is verified whether the individual has really acquired certain ability. Finally, in the transfer stage it is checked whether a motor behavior can adapt to changes in the task performed (15).

Previous studies have used different tasks to assess ML, including basketball games $(16,17)$, trail making tests (18), virtual reality with a cell phone (19), and the use of software in a computer $(15,20,21)$, such as the maze test used in this study, which was performed in a virtual computer environment and in a real environment, using a sheet of paper. The maze test has already been used to assess people with typical development (22), deficiency (15), and syndromes (23), as well as older adults (24).

As mentioned before, individuals institutionalized in shelters may suffer impairments that may be detrimental to their development and to motor learning. Moreover, there are only very few studies on the development of motor skills in institutionalized individuals. Thus, this study aimed to investigate motor learning in children and adolescents living in shelters, and compare them with subjects living a family context.

\section{Methods}

This was a cross-sectional study, with data collected between September and December 2015. Ethical approval was obtained under CAAE: 46157215.0.0000.551. Thirty-six subjects (children and adolescents) participated in this study. Of these, 18 lived in a shelter in the countryside of the state of São Paulo (experimental group - EG) and 18 did not live in shelters (control group - CG). All subjects participated in an educational and sports project in that same city. These subjects were matched by age and sex with the EG.

Inclusion criteria were subjects aged 6-18 years, who had signed an assent statement and whose legal guardians authorized involvement in the study by signing an informed consent form. Exclusion criteria were having neurological impairment or a visual, cognitive or physical impairment that might prevent comprehension or completion of the task. Of the children and adolescents who did not participate in the study, four had neurological impairments and two were younger than the age group targeted in this study.

Motor learning was assessed in a classroom and subjects were sat in chairs and desks to complete the maze test. The maze test used in this study was developed and used by Rodrigues et al. (25) (Figure 1). It was performed in a virtual environment in a 15inch Samsung ${ }^{\circledR}$ Notebook, using a regular optical mouse (Figure 2), and in a real environment with the same proportions of the virtual one, using A4 size sulphite paper and a BIC ${ }^{\circledR}$ ballpoint pen (Figure 2).

The maze test is composed of one spatial memory activity in which the subject has to go through a path with only one entry/exit. The time needed to complete the task was measured using a stopwatch. Participants were instructed to use their preferred hand to complete the test.

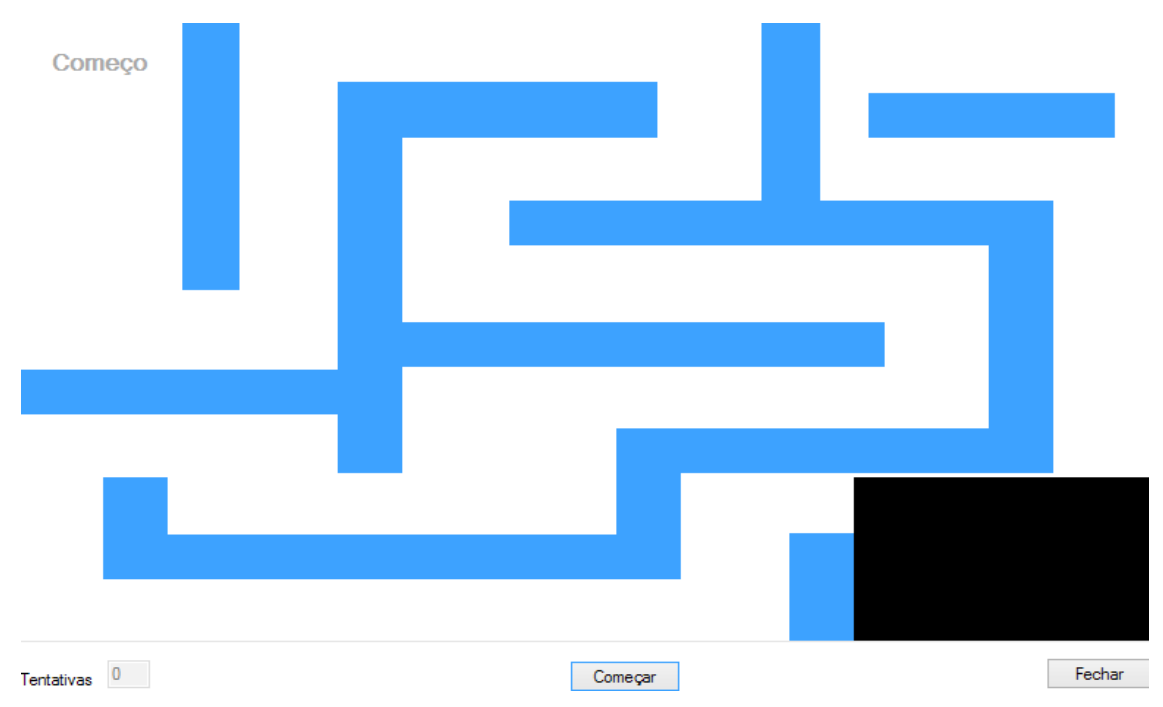

Figure $\mathbf{1}$ - Maze test adopted for the assessment protocol 


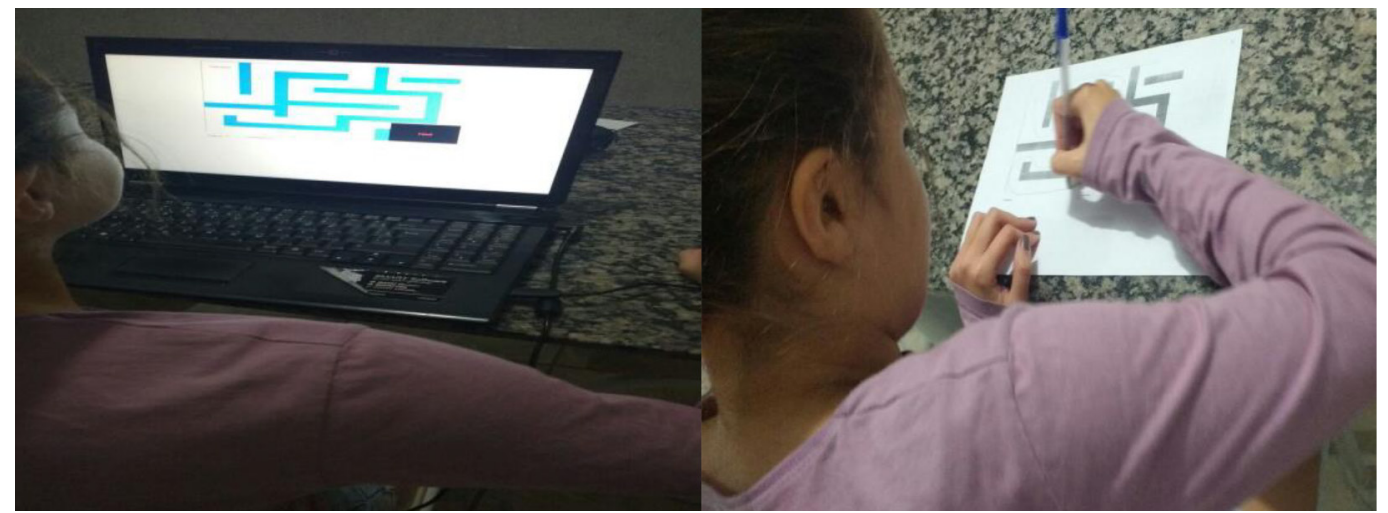

Figure 2 - Participant completing the maze test on a computer and on paper.

The assessment protocol was divided into three distinct stages: acquisition (task performed on a computer, in a virtual environment), retention (the same task performed in a virtual environment) and transfer (task performed on a paper sheet, in a real environment). The study protocol was standardized andequally administered by the same examiners to all EG and CG participants. In the acquisition stage, all children and adolescents performed a total of 30 repetitions of the maze task on the computer. After a five-minute rest period, participants started the retention stage, in which they had to complete another five repetitions of the same maze task on the computer. In the transfer stage, participants had to perform another five repetitions of the same maze task, only this time on a paper sheet.

The data collected was organized into blocks of five trials and analyzed using the statistical software
GraphPad Prism. Data normality was determined by the Shapiro Wilk test. Due to data normality, a Wilcoxon intragroup comparison for dependent samples was done. The Mann Whitney test was used for intergroup comparisons. The non-parametric Kruskal-Wallis test and Dunn's post-test comparison were applied for analysis of the three variables (last acquisition block, retention and transfer). The level of significance was set at $5 \%$ and the data was expressed in median and interquartile range.

\section{Results}

The mean age of the sample was $12.2 \pm 3.24$ years, with 10 female and 26 male. We found that the EG had longer task performance time than the CG in all stages of the protocol, with significant difference between groups $\left(\mathrm{p}<0.0001^{*}\right)$ (Table 1$)$.

Table 1 - Comparison of variables (seconds) between groups. Data expressed in median and interquartile range (25-78\%)

\begin{tabular}{lcccc}
\hline \multicolumn{1}{c}{ Z } & & EG & CG & Value $p$ \\
\hline Acquisition & A1 & $11.05[8.50-14.85]$ & $7.65[5.95-10.23]$ & $<0.0001^{*}$ \\
& A2 & $9.39[7.39-12.01]$ & $6.10[5.40-7.92]$ & $<0.0001^{*}$ \\
& A3 & $8.49[6.45-10.90]$ & $5.80[5.00-6.90]$ & $<0.0001^{*}$ \\
& A4 & $8.14[6.06-10.95]$ & $5.60[4.90-6.80]$ & $<0.0001^{*}$ \\
& A5 & $8.01[6.25-10.03]$ & $5.55[4.67-6.72]$ & $<0.0001^{*}$ \\
& A6 & $8.02[6.86-10.23]$ & $5.50[4.50-6.82]$ & $<0.0001^{*}$ \\
\hline Retention & & $8.20[7.09-9.89]$ & $5.35[4.50-6.22]$ & $<0.0001^{*}$ \\
Transfer & & $8.30[6.28-11.43]$ & $5.30[4.90-6.82]$ & $<0.0001^{*}$ \\
\hline
\end{tabular}

Note: EG: experimental group; CG: control group; A1: first acquisition block; A2: second acquisition block; A3: third acquisition block; A4: fourth acquisition block; A5: fifth acquisition block; A6: sixth acquisition block. 
We found a significant reduction in task performance between the first acquisition block (A1) and the last acquisition block (A6) in both groups (GE: $\mathrm{p}<0.0001^{*}$ ) (CG: $\mathrm{p}<0.0000^{*}$ ). We also found that the difference between A1 and A6 for both groups were similar (Table 2).

Table 2 - Intergroup comparison between $\mathrm{Al}$ and $\mathrm{A} 6$ and absolute delta difference (seconds). Data expressed in median and interquartile range (25-75\%)

\begin{tabular}{lccc}
\hline & A1 & A6 & Value $p$ \\
\hline \multirow{2}{*}{ CG } & $\begin{array}{c}7.65 \\
{[5.97-10.23]}\end{array}$ & $\begin{array}{c}5.50 \\
{[4.50-6.82]}\end{array}$ & $<0.0000^{*}$ \\
\hline \multirow{2}{*}{ EG } & $\begin{array}{c}11.05 \\
{[8.50-14.85]}\end{array}$ & $\begin{array}{c}8.02 \\
{[6.86-10.23]}\end{array}$ & $<0.0001^{*}$ \\
\hline \multirow{2}{*}{ Delta } & $\begin{array}{c}-2.00 \\
{[-4.52-(0.1750)]}\end{array}$ & $\begin{array}{c}-2.05 \\
{[-6.67-(-0.2825)]}\end{array}$ & 0.3159 \\
\hline
\end{tabular}

Note: CG: control group; EG: experimental group; A1: first acquisition block; A6: sixth acquisition block.

When comparing A6, retention and transfer, we found that both groups had the same task performance time in all the above mentioned stages, with no significant difference between groups (Table 3).

Table 3 - Comparison of variables (seconds) between A6, Retention and Transfer

\begin{tabular}{ccccc}
\hline & A6 & Retention & Transfer & Value $p$ \\
\hline \multirow{2}{*}{ CG } & 5.50 & 5.35 & 5.30 & \multirow{2}{*}{0.499} \\
& {$[4.50-6.82]$} & {$[4.50-6.22]$} & {$[4.90-6.82]$} & \\
\hline \multirow{2}{*}{ EG } & 8.02 & 8.20 & 8.30 & \multirow{2}{*}{0.895} \\
& {$[6.86-10.23]$} & {$[7.09-9.89]$} & {$[6.28-11.43]$} & \\
\hline
\end{tabular}

Note: CG: control group; EG: experimental group; A6: sixth acquisition block.

\section{Discussion}

This study used the maze test to investigate ML and found that children and adolescents who lived in shelters had longer task performance time in all stages of the study when compared to their controls. This finding may be explained by a possible developmental deficit in institutionalized individuals. Chaves et al. (26) assessed 44 institutionalized children and adolescents. The authors investigated anthropometric data and children's development using a semistructured instrument to consult medical records and performing physical examinations (assessing weight, height, cephalic perimeter, thoracic perimeter, child development milestones and, in younger children, primitive reflexes). The growth of children who live in shelters was considered satisfactory, but they showed a delay in their psychological and social development.

We also found a reduction in task performance time between the first (A1) and the last task performance block (A6) in both groups. This evidences that task training during this stage led to an improvement in performance, even if the EG had longer task performance time than the CG. According to Tallet et al. (27), the learning process occurs through memory storage. Thus, individuals perform well in specific activities when they train them for a long period of time. This explains the evolution of the groups assessed in this study, as they trained the task several times during the acquisition stage.

When comparing the variables of the last acquisition block, Retention and Transfer, in both groups, we found no changes in task performance time, not even when comparing task performance in a virtual environment (Acquisition and Retention) and in a real environment (Transfer).

In this study, we used a real maze in the transfer stage to analyze the process of adaptation to a task change. Probably because the task was easy to understand and the subjects had already had contact with the virtual reality, the change to a real interface did not represent an obstacle to performance and the performance time of both groups remained constant. Nevertheless, although the EG showed no changes in task performance time between test batteries, its performance time was still longer than that of the CG, which confirms the deficit in the EG group.

Previous studies $(28,29)$ confirm that individuals institutionalized in shelters usually have impaired psychomotor development when compared to noninstitutionalized individuals. This may be detrimental to the performance of motor activities such as the maze test.

The findings of this study indicate that the EG and the CG evolved in a similar way in the performance of the motor activity maze. Notwithstanding, the EG had a longer performance time, probably due to the need of greater stimuli and more training for an effective learning experience. In this context, Torquato etal. (30) state that an individual's intellectual, motor and emotional development requires stimuli that may be provided by an affective relationship in the context of family interaction. An individual who lives in a shelter 
is usually deprived of receiving stimuli generated by interaction among family members. With time, however, these children and adolescents look for affection in their peers, creating a family environment where these stimuli can be generated (30). This may favor their development.

The authors (30) also report that these individuals also have an impaired neuro-psychomotor development, although with no significant results. This fact may indicate once again that individuals from the EG and the CG have a similar development, but the EG has a longer performance time.

The finding for the CG (i.e., no changes in task performance time throughout all testing stages) is probably due to fact that the task was easy to perform for all these subjects. According to Fox et at. (31), when individuals live in a stable family environment they show significant differences in cognitive development, language, memory and speed of information processing during performance of a task, when compared to institutionalized individuals. This explains the longer task completion time demonstrated by the EG.

The results obtained in this study allow us to affirm that the maze test is an important tool for the analysis of motor learning, because its completion requires basic motor skills, the test is easily used in research and it can be administered both to typical and atypical individuals (24), such as older adults, children with neurological injury or with delayed development - like the ones in this study. Nonetheless, in this task, time is seen as quantitative variable of motor learning and hence we used the maze test to investigate subjects' ability to perform the task the best they could, as measured by movement time.

During this study, we were not able to find many studies on ML in children and adolescents living in shelters, regardless of the task selected for analysis. This fact potentiates the results found in this study and reveals the importance of assessing motor learning in this population.

As a study limitation, we note the relatively small sample size due to the smaller number of institutionalized children and adolescents in the selected age group. We suggest the conduction of other studies with bigger samples and, quantitative and qualitative analyses of learning motor.

\section{Conclusion}

Individuals living in shelters showed a motor learning deficit, as evidenced by longer task performance time when compared to their controls. Nevertheless, both groups performed the task in a similar manner.

\section{References}

1. Brasil. Presidência da República, Subchefia para Assuntos Jurídicos. Lei no 8.069 de 13 de julho de 1990. Dispõe sobre o Estatuto da Criança e do Adolescentes e dá outras providências. Brasília, DF; 1990 [cited 2015 May 20]. Available from: https://tinyurl.com/ q4t9ldo

2. Orionte I, Souza SMG. O significado do abandono para crianças institucionalizadas. Psicol Rev (Belo Horizonte). 2005;11(17):29-46.

3. Sheridan MA, Fox NA, Zeanah CH, McLaughlin KA, Nelson III CA. Variation in neural development as a resul.t of exposure to institutionalization early in childhood. Pnas. 2012;109(32):12927-32.

4. Souza G. Levantamento mostra que 36,5 mil crianças e adolescentes vivem em abrigos. Agência CNJ de Notícias, 2011 Dez 26. [cited 2015 May 18]. Available from: https://tinyurl.com/lun6ut4

5. Nelson III CA, Zeanah CH, Fox NA, Marshall PJ, Smyke AT. Cognitive recovery in socially deprived young children: The Bucharest Early Intervention Project. Science. 2007;318(5858):1937-40.

6. Cavalcante LLC, Magalhães CMC, Pontes FAR. Institucionalização precoce e prolongada de crianças: discutindo aspectos decisivos para o desenvolvimento. Aletheia. 2007;25:20-34.

7. Windsor J, Benigno JP, Wing CA, Carroll PJ, Koga SF, Nelson CA, et al. Effect of foster care on young children's language learning. Child Dev. 2011;82(4):1040-6.

8. Kreppner JM, O’Connor TG, Rutter M. Can inattention/overactivity be an institutional deprivation syndrome? J Abnorm Child Psychol. 2001;29(6):513-28. 
9. Zeanah CH, Egger HL, Smyke AT, Nelson CA, Fox NA, Marshall PJ, et al. Institutional rearing and psychiatric disorders in Romanian preschool children. Am J Psychiatry. 2009;166(7):777-85.

10. Santos BCA, Ribeiro MCC, Ukita GM, Pereira PM, Duarte FW, Custódio EM. Característica emocionais e trações de personalidades em crianças institucionalizadas e não institucionalizadas. Bol Psicol. 2010;60(133):139-52.

11. Chiviacowsky S, Tani G. Efeitos da frequência do conhecimento de resultados na aprendizagem de uma habilidade motora em crianças. Rev Paul Educ Fis. 1997;11(1):15-26.

12. Cano-de-la-Cuerda R, Molero-Sánchez A, CarrataláTejadaa M, Alguacil-Diego IM, Molina-Rueda F, Miangolarra-Page JC, et al. Theories and control models and motor learning: Clinical applications in neurorehabilitation. Neurologia. 2015;30(1):32-41.

13. Magill RA. Aprendizagem motora: conceitos e aplicações. 5th ed. São Paulo: Edgard Blücher; 2000.

14. Lent R. Cem bilhões de neurônios: conceitos fundamentais de neurociência. Rio de Janeiro: Atheneu; 2001. p. 587-617.

15. Monteiro CBM, Jakabi CM, Palma GCA, Pasin CT, Meira Jr CM. Aprendizagem motora em crianças com paralisia cerebral. Rev Bras Crescimento Desenvolv Hum. 2010;20(2):250-62.

16. Ugrinowitsch H, Dantas LEPBT. Efeito do estabelecimento de metas na aprendizagem do arremesso do basquetebol. Rev Port Cienc Desporto. 2002;2(5):58-63.

17. Palhares LR, Bruzi AT, Fialho JVAP, Ugrinowitsch AAC, Benda RN, Ugrinowitsch H. O Estabelecimento de Metas na Aprendizagem Motora: uma Proposta de Avaliação do Comprometimento. Rev Bras Cienc Mov. 2007;15(3):31-8.

18. Bertolucci PHF, Okamoto IH, Brucki SMD, Siviero MO, Toniolo Neto J, Ramos LR. Applicability of the CERAD Neuropsycholgical Batery to Brazilian elderly. Arq Neuropsiquiatr. 2001;59(3A):532-6.
19. Menezes LDC, Gomes KSC, Massetti T, Silva TD, Possebom WF, Capelini CM, et al. Motor learning in mobile (cell phone) device in Down syndrome patients - pilot project. MedicalExpress (São Paulo, online). 2015;2(4):M150405.

20. Monteiro CBM, Massetti T, Silva TD, van der Kamp J, Abreu LC, Leone C, et al. Transfer of motor learning from virtual to natural environments in individuals with cerebral palsy. Rev Dev Disabil. 2014;35(10):2430-7.

21. Scattone C, Masini EFS. O software educativo no processo de ensino- aprendizagem: Um estudo de opnião de alunos de uma quarta série do ensino fundamental. Rev Psicopedag. 2007;47(75):240-50.

22. Diniz AB, Basso L, Hashiguchi D, Beltrão NB, Correia ERFG, Oliveira DS, et al. Aprendizagem de uma habilidade motora seriada em diferentes estágios de desenvolvimento. Rev Bras Educ Fis Esp. 2012;26(1):119-28.

23. Possebom WF, Silva TD, Ré AHN, Massetti T, Belisário LZ, Ulian E, et al. Aprendizagem motora em pessoas com síndrome de Down: Tarefa de labirinto no computador. Temas Desenvolv. 2013;19(104):54-60.

24. Souza DE, França FR, Campos TF. Teste de Labirinto: Instrumento de Análise na Aquisição de uma Habilidade Motora. Rev Bras Fisioter. 2006;10(3):355-60.

25. Rodrigues BH, Silvério CP, Franzini Jr CAA, Santos CP, Caldeira DT, Silva BC, et al. Aprendizado motor com aplicação de labirinto virtual e real na síndrome de down. Colloquium Vitae. 2015;7(3):62-70.

26. Chaves CMP, Lima FET, Mendonça LBA, Custódio IL, Matias EO. Avaliação do crescimento e desenvolvimento de crianças institucionalizadas. Rev Bras Enferm. 2013;66(5):668-74.

27. Tallet J, Albaret JM, Rivière J. The role of motor memory in action selection and procedural learning: insights from children with typical and atypical development. Socioaffect Neurosci Psychol. 2015;5:28004. 
28. Levin AR, Zeanah Jr CH, Fox NA, Nelson CA. Motor Outcomes in Children Exposed to Early Psychosocial Deprivation. J Pediatr. 2014;164(1):123-9.

29. Bos K, Zeanah CH, Fox NA, Drury SS, McLaughlin KA, Nelson CA. Psychiatric Outcomes in Young Children with a History of Institutionalization. Harv Rev Psychiatry. 2011;19(1):15-24.

30. Torquato JA, Paes JB, Bento MCC, Saikai GMPN, Souto JN, Lima EAM, et al. Prevalência de atraso do desenvolvimento neuropsicomotor em préescolares. Rev Bras Crescimento Desenvolv Hum. 2011;21(2):259-68.
31. Fox NA, Almas AN, Degnan KA, Nelson CA, Zeanah $\mathrm{CH}$. The effects of severe psychosocial deprivation and foster care intervention on cognitive development at 8 years of age: findings from the Bucharest Early Intervention Project. J Child Psychol Psychiatry. 2011;52(9):919-28.

Received in $06 / 14 / 2016$

Recebido em 14/06/2016

Approved in 03/14/2017

Aprovado em 14/03/2017 